\title{
The Value of Red Blood Cells (Rbc) Indices and Osmotic Fragility Test as Screening Tests in Malay Pregnant Women with Alpha Thalassaemia
}

Rosline Hassan ${ }^{1 *}$, Nurul Ain Fathma Abdullah1, Rosnah Bahar ${ }^{1}$, Selamah Ghazali ${ }^{1}$ and Nor Aliza Abdul Ghaffar ${ }^{2}$

${ }^{1}$ Department of Haematology, Universiti Sains Malaysia, Kubang Kerian Kelantan, Malaysia

${ }^{2}$ Department of Obstetrics and Gynaecology, Universiti Sains, Malaysia, Kubang Kerian Kelantan, Malaysia

\begin{abstract}
Red blood cell (RBC) parameters obtained from hematology analyser has been very useful as the first line screening for thalassaemia. The changes are prominent in most type of $\beta$-thalassaemia but milder in $\alpha$-thalassaemia. RBC parameters could have been normalized especially during pregnancy and in such situation screening these patients would require a different protocol. Blood samples from two hundred (200) Malay pregnant women attended obstetric clinic at Hospital Universiti Sains Malaysia (HUSM) were collected to screen for double a-gene deletion (-SEA, and -THAI), and the two single $\alpha$-globin gene deletion $\left(-\alpha^{3.7}\right.$ and $\left.-\alpha^{4.2}\right)$. Standard hematological analyses including red blood cell count and indices, and hemoglobin quantitation were performed on the blood samples. Of these, sixteen were excluded as they had $\mathrm{HbA}_{2}$ levels more than $4 \%$ and were diagnosed as $\mathrm{HbE}$ or $\beta$-thalassaemia trait. Then, multiplex GAP polymerase chain reaction (PCR) analyses of $\alpha$-globin gene were performed on the remaining 184 blood samples. Total of 17 from 184 subjects confirmed to have $\alpha$-thalassaemia $\left(-\alpha^{3.7} / \alpha \alpha\right.$ and ${ }^{-S E A} / \alpha \alpha$ genotype). The RBC indices were compared between those with $\alpha$-thalassaemia and normal pregnant women and they were significantly different. $-\alpha^{3.7} \mathrm{~kb}$ single gene deletion $(8.1 \%)$ was the commonest type followed by double gene South East Asia (-SEA) deletion (1.1\%). We conclude that mean corpuscular volume (MCV) and mean corpuscular hemoglobin $(\mathrm{MCH})$ with the cut off value of less than $86.3 \mathrm{fl}$ and $27.4 \mathrm{pg}$ respectively are two useful RBC indices which can be used for screening of $\alpha$-thalassaemia in pregnant women.
\end{abstract}

Keywords: Alpha thalassemia; Multiplex GAP PCR; Osmotic fragility test (OFT); Pregnant women; Red blood cell (RBC) indices

\section{Introduction}

Thalassaemia is a group of genetic, inherited disorders of the blood. More specifically, it is a disorder of the globin gene synthesis. Thalassaemia is a major health problem worldwide and it is common in people of Asian descent and has emerged as public health problem in Malaysia [1].

There are two common types of thalassaemia which is $\alpha$ - and $\beta$ thalassaemia. The $\alpha$-thalassaemia is mainly caused by a large deletion of the $\alpha$-globin gene and occurs when one or more of the four alphas (a) chain genes fail to function. $\alpha$-thalassaemia is the one of the most common inherited disorder of hemoglobin synthesis and commonly found in Southeast Asian, Mediterranean and Middle Eastern population [2]. While, $\beta$-thalassaemia generally caused by point mutations affecting the $\beta$-globin gene leading to a reduction $\left(\beta^{+}\right)$or absence $\left(\beta^{0}\right)$ of $\beta$-globin gene production.

$\alpha$-thalassaemia can be classified into two types; $\alpha$-thalassaemia 1 ( $\alpha^{0}$-thalassaemia), the deletion of both $\alpha 1$ - and $\alpha 2$ - globin genes; and $\alpha$-thalassaemia 2 ( $\alpha^{+}$-thalassaemia) where only one a-globin gene deletion has occurred [3]. An individual with only one a-globin deletion or heterozygous for a+-thalassaemia normally is a silent carrier ( $\alpha \alpha / \alpha-)$ [4].

Many methods are currently used for screening and diagnosis of $\alpha$-thalassaemia. Simple erythrocyte osmotic fragility (OF) test is commonly used for screening of $\alpha$-thalassaemia disorder followed by high performance liquid chromatography (HPLC) and polymerase chain reaction (PCR) $[5,6]$.

Identification of carrier state in early pregnancy using screening protocol for each population is important for the prevention and control of this disease. Therefore, the aim of this study is to identify the RBC indices and its cut off level as the screening tool for common deletional types of a-thalassaemia in pregnant women in Hospital Universiti Sains Malaysia (HUSM).

\section{Materials and Methods}

A total of two hundred (200) Malay pregnant women, attending for antenatal check-up at Obstetrics \& Gynecology Clinic in Hospital Universiti Sains Malaysia (HUSM) were recruited into this study. Written informed consent was taken from them. The study protocol was reviewed and approved by the Research and Ethics Committee, School of Medical Sciences, Universiti Sains Malaysia, Kelantan Health Campus. A total of $3 \mathrm{ml}$ whole blood was collected in ethylene diamine tetra acetic acid (EDTA) bottle and immediately screened for $a$-thalassaemia using the modified one tube osmotic fragility (OF) test following the manufacturer's protocols as described in earlier study [5]. Full blood count parameters were determined using an automated blood counter (SYSMEX ${ }^{\bullet}$ KX-21, Sysmex Corporation, Kobe, Japan) for all blood samples. The percentage of hemoglobin $\mathrm{A}_{2}\left(\mathrm{HbA}_{2}\right)$ and hemoglobin $\mathrm{F}(\mathrm{HbF})$ were measured for all samples by using Bio-Rad VARIANT Hemoglobin Testing System (Variant, Bio-Rad Laboratories, Hercules, CA). For subject who had an $\mathrm{HbA}_{2}$ level $<4 \%$, molecular diagnostic techniques were used to detect the type of $\alpha$-thalassaemia.

${ }^{*}$ Corresponding author: Rosline Hassan, Department of Haematology, Schoo of Medical Sciences, Universiti Sains Malaysia, 16150 Kubang Kerian, Kelantan, Malaysia, Tel: 609 7676191; Fax: 609 7673333; E-mail: roslin@kb.usm.my

Received October 11, 2013; Accepted November 25, 2013; Published November 30, 2013

Citation: Hassan R, Fathma Abdullah NA, Bahar R, Ghazali S, Abdul Ghaffar NA (2013) The Value of Red Blood Cells (Rbc) Indices and Osmotic Fragility Test as Screening Tests in Malay Pregnant Women with Alpha Thalassaemia. Clinics Mother Child Health 11: 154. doi: 10.4172/2090-7214.1000154

Copyright: (c) 2013 Hassan R, et al. This is an open-access article distributed under the terms of the Creative Commons Attribution License, which permits unrestricted use, distribution, and reproduction in any medium, provided the original author and source are credited. 
Citation: Hassan R, Fathma Abdullah NA, Bahar R, Ghazali S, Abdul Ghaffar NA (2013) The Value of Red Blood Cells (Rbc) Indices and Osmotic Fragility Test as Screening Tests in Malay Pregnant Women with Alpha Thalassaemia. Clinics Mother Child Health 11: 154. doi: 10.4172/20907214.1000154

Genomic deoxyribonucleic acid (DNA) was extracted and purified from whole blood sample using the Gentra Puregene Blood Kit (Qiagen, Germany). Deletion analysis of the a-globin gene was carried out using multiplex GAP PCR with the primers designed to detect 2 double $\alpha$-gene deletion (-SEA, and -THAI), and the 2 single $\alpha$-globin gene deletion $\left(-\alpha^{3.7}\right.$ and $\left.-\alpha^{4.2}\right)$.

A total volume of $25 \mu \mathrm{l}$ of reaction mixture contained $200 \mathrm{ng} / \mu \mathrm{l}$ of genomic DNA in final concentration of 1X PCR buffer (Qiagen, Germany), $0.2 \mathrm{mM}$ of deoxyribonucleotide triphosphate (dNTP) mix (Applied Biosystems, California, USA), $1.5 \mathrm{mM}$ magnesium chloride $\left(\mathrm{MgCl}_{2}\right)$ (Qiagen, Germany), 10-20 pmol of each specific primers (Sigma Proligo, Singapore), $2.5 \mathrm{U}$ of Hot Star Taq DNA polymerase (Qiagen, Germany), 1X Q-Solution (Qiagen, Germany) and double distilled water $\left(\mathrm{ddH}_{2} \mathrm{O}\right)$. The reaction amplification started with initial denaturation at $95^{\circ} \mathrm{C}$ for 15 minutes, followed by 30 cycles of denaturation at $97^{\circ} \mathrm{C}$ for 45 seconds, annealing at $60^{\circ} \mathrm{C}$ for 75 seconds, extension at $72^{\circ} \mathrm{C}$ for 150 seconds and final extension at $72^{\circ} \mathrm{C}$ for 5 minutes. Amplified products were electrophoreses in $1 \%$ agarose gel in $1 \mathrm{X}$ Tris-Borate-EDTA (TBE) buffer. The gel was stained with ethidium bromide $(\mathrm{EtBr})$ placed on transluminator and photographed.

\section{Statistical Analysis}

Data entry and analysis was done using IBM Statistical Package for Social Sciences (SPSS) version 20 for windows (IBM Inc, USA). Means and standard deviations were calculated for numerical variables. Frequencies, percentages and chi-square were calculated for all categorical variables.

\section{Results}

A total of 200 Malay pregnant women were recruited into this study. They came for their first antenatal check-up at Obstetric clinic, Hospital Universiti Sains Malaysia, Malaysia. 73\% were in their first trimester, $22 \%$ second and $5 \%$ third trimester. Their mean age was $31.5 \pm 9.4$ year old. Of these, 16 were later excluded because they were diagnosed as having $\mathrm{HbE}$ or $\beta$-thalassaemia trait. The remaining 184 women were available for molecular analysis. Out of 184 women, 17 were detected to have $\alpha$-thalassaemia while 167 were normal.

Hematological parameters were compared between $\alpha$-thalassaemia carrier and normal individuals. Analysis of hematologic data from the subjects showed significantly difference in $\mathrm{MCV}$ and $\mathrm{MCH}$ between normal and $\alpha$-thalassaemia carriers $(\mathrm{p}<0.001$; Table 1$)$.

Based on the receiver operating characteristic (ROC) curve for the $\mathrm{MCV}$ and $\mathrm{MCH}$, the best cut-off point for predicting the presence of the $\alpha$-thalassaemia carrier in pregnant women was $86.3 \mathrm{fL}$ giving $77 \%$

\begin{tabular}{|c|c|c|c|}
\hline $\begin{array}{c}\text { Hematological } \\
\text { Parameters }\end{array}$ & a-thalassaemia trait & Normal & \multirow{2}{*}{$\boldsymbol{p}$-value } \\
\cline { 1 - 3 } $\mathbf{H b}(\mathbf{g} / \mathbf{d L})$ & $11.32(0.87)$ & $11.61(1.06)$ & 0.835 \\
\hline MCV (fL) & $82.32(5.69)$ & $88.60(4.75)$ & $0.000^{*}$ \\
\hline MCH (pg) & $25.97(2.11)$ & $28.60(2.14)$ & $0.000^{*}$ \\
\hline HbA2 (\%) & $2.98(0.31)$ & $3.00(0.34)$ & 0.888 \\
\hline HbF (\%) & $0.34(0.37)$ & $0.36(0.49)$ & 0.269 \\
\hline
\end{tabular}

**independent $t$ test showed significant at $\mathrm{p}<0.005$

* Alleles are represented as follows: Hb, hemoglobin; MCV, mean corpuscular volume; $\mathrm{MCH}$, mean corpuscular hemoglobin; $\mathrm{HbA}_{2}$, hemoglobin $\mathrm{A}_{2} ; \mathrm{SD}$, standard deviation; fL, femtoliter; pg, picograms.

Table 1: Mean $\pm S D$ of the difference hematological parameters in a-thalassaemia trait and normal subject. of sensitivity and $71 \%$ of specificity (Figure 1) and $27.4 \mathrm{pg}$ giving $76 \%$ of sensitivity and $71 \%$ of specificity, respectively (Figure 2).

A total of 16 subjects were positive by one-tube osmotic fragility test however 17 were confirmed as $\alpha$-thalassaemia based on molecular testing. Among 17 who were carrier of $\alpha$ - thalassaemia, 4 (3 heterozygous of $-a^{3.7} \mathrm{~kb}$ deletion and 1 --SEA type deletion) were consistently positive with OF while the other 13 were negative. Among 184 pregnant women studied, 17 (9.2\%) were found to carry a-thalassaemia gene (Table 2). In this study group, two $\alpha$-thalassaemia genotypes were observed: $-\alpha^{3.7 /}$ $\alpha \alpha$ and ${ }^{-S E A} / \alpha \alpha$. The most common genotype was heterozygous $-\alpha^{3.7}$ rightward single gene deletion (8.1\%) followed by ${ }^{- \text {SEA }}$ deletion (1.1\%). $a^{4.2}$ rightward single gene deletion and ${ }^{- \text {THAI }}$ deletion were not detected.

\section{Discussion}

Thalassaemias are the most common inherited disorder worldwide and represent as a major health problem in many areas [7]. $a$-thalassaemia is the most prevalent and the diagnosis is challenging especially during pregnancy. A total of 200 Malay pregnant women who

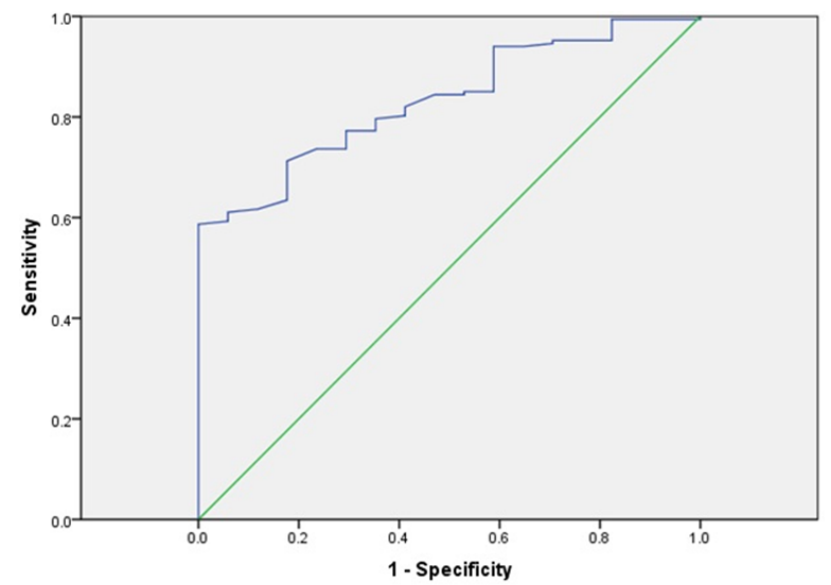

Figure 1: ROC curve for MCV predicting the presence of the $\alpha$-thalassaemia carrier in pregnant women. (Area under the curve, 0.83; $95 \%$ confidence interval, 0.76-0.91)

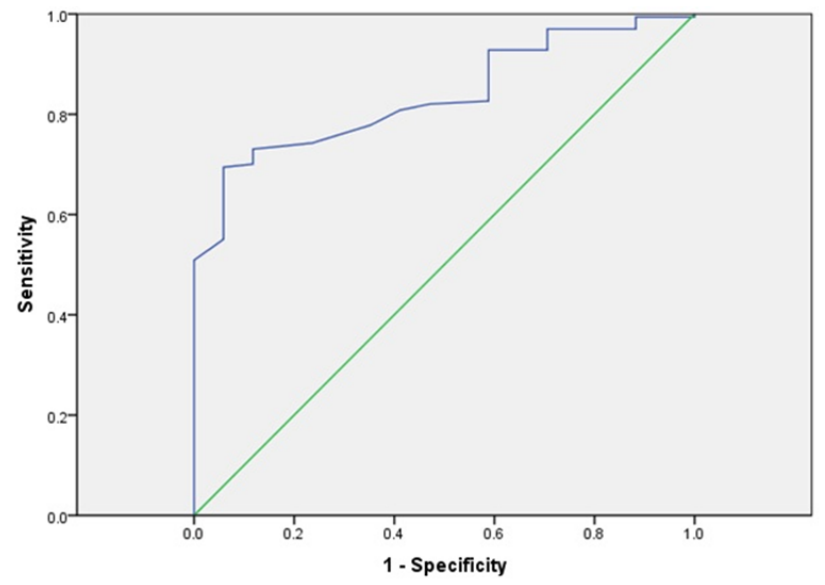

Figure 2: ROC curve for $\mathrm{MCH}$ predicting the presence of the $\alpha$-thalassaemia carrier in pregnant women. (Area under the curve, 0.84; 95\% confidence interval, 0.77-0.91) 
Citation: Hassan R, Fathma Abdullah NA, Bahar R, Ghazali S, Abdul Ghaffar NA (2013) The Value of Red Blood Cells (Rbc) Indices and Osmotic Fragility Test as Screening Tests in Malay Pregnant Women with Alpha Thalassaemia. Clinics Mother Child Health 11: 154. doi: 10.4172/20907214.1000154

Page 3 of 4

\begin{tabular}{|c|c|c|c|c|c|}
\hline \multirow{2}{*}{ Patient No } & \multicolumn{4}{|c|}{ Parameter } & \multirow{2}{*}{ a genotyping } \\
\hline & $\mathrm{Hb}$ & $\mathrm{MCH}$ & MCV & OFT & \\
\hline 1 & 12.6 & 27.8 & 88.1 & negative & $-\alpha 3.7 / \alpha \alpha$ \\
\hline 2 & 11.4 & 27.3 & 86.6 & negative & $-\alpha 3.7 / \alpha \alpha$ \\
\hline 3 & 12.3 & 26.9 & 86.2 & negative & $-\alpha 3.7 / \alpha \alpha$ \\
\hline 4 & 11.1 & 27.2 & 86.5 & negative & $-\alpha 3.7 / \alpha \alpha$ \\
\hline 5 & 11.2 & 26.9 & 84.9 & negative & $-\alpha 3.7 / \alpha \alpha$ \\
\hline 6 & 10.8 & 28.6 & 87.6 & negative & $-\alpha 3.7 / \alpha \alpha$ \\
\hline 7 & 11.5 & 27.5 & 85.2 & negative & - $\alpha 3.7 / \alpha \alpha$ \\
\hline 8 & 11.9 & 24.7 & 79.5 & negative & $-\alpha 3.7 / \alpha \alpha$ \\
\hline 9 & 11.2 & 27.5 & 87.5 & negative & $-\alpha 3.7 / \alpha \alpha$ \\
\hline 10 & 10.7 & 24.4 & 79.7 & negative & - $\alpha 3.7 / \alpha \alpha$ \\
\hline 11 & 11.8 & 24 & 73.6 & negative & - $\alpha 3.7 / \alpha \alpha$ \\
\hline 12 & 13.2 & 27.4 & 85.1 & negative & $-\alpha 3.7 / \alpha \alpha$ \\
\hline 13 & 10.4 & 25.7 & 80.4 & positive & $-\alpha 3.7 / \alpha \alpha$ \\
\hline 14 & 10.4 & 25.7 & 80.5 & positive & - $\alpha 3.7 / \alpha \alpha$ \\
\hline 15 & 11.8 & 27 & 85.4 & positive & - $\alpha 3.7 / \alpha \alpha$ \\
\hline 16 & 10.1 & 20.9 & 69.2 & negative & __SEA/ $\alpha \alpha$ \\
\hline 17 & 10.1 & 22.1 & 73.5 & positive & __SEA/ $\alpha \alpha$ \\
\hline
\end{tabular}

aData presented as raw data.

${ }^{\mathrm{b}}$ Alleles are represented as follows: $-\mathrm{a}^{3.7} / \mathrm{a \alpha}=3.7 \mathrm{~kb}$ deletion, ${ }^{-\mathrm{SEA}} / \mathrm{a \alpha}=\mathrm{SEA}$ deletion. $\mathrm{Hb}$, hemoglobin; $\mathrm{MCV}$, mean corpuscular volume; $\mathrm{MCH}$, mean corpuscular hemoglobin; OFT, Osmotic Fragilit y Test.

Table 2: Characteristic features of 17 a-thalassaemia carrier among 184 pregnant women at HUSM.

attended an antenatal checkup at Hospital Universiti Sains Malaysia were screened for $\alpha$-thalassaemia. Of these, 16 were excluded as they were diagnosed as $\beta$-thalassaemia/HbE trait. Out of 184,17 cases were identified with $\alpha$-thalassaemia carrier.

Full blood count with red blood cell indices usually were used as the initial method for screening of $\alpha$-thalassaemia [5]. The red blood cell indices used for screening included hemoglobin count $(\mathrm{Hb})$, mean corpuscular volume $(\mathrm{MCV})$, mean corpuscular hemoglobin $(\mathrm{MCH})$, hemoglobin $\mathrm{A}_{2}$ count $\left(\mathrm{HbA}_{2}\right)$ and hemoglobin $\mathrm{F}$ count $(\mathrm{HbF})$.

$\mathrm{MCV}$ and $\mathrm{MCH}$ are two routinely parameters carried out worldwide during pregnancy. It is cheap, quiet and simple method especially in area with highest incidence. The importance of thalassaemia screening during antenatal follow-up is mainly to identify patients with two gene deletion who may be at risk to have hydrops baby. Further molecular testing may also required in highly suspicious case in order to avoid unnecessary supplementation of iron tablet.

The MCV cut-off values used for thalassaemia screening vary widely and cut-off value between 75 and $80 \mathrm{fL}$ have been used in most institutions as previously reported $[5,8,9]$. Based on our ROC curve of MCV values, our study suggests the best cut-off point for predicting the present of $\alpha$-thalassaemia in pregnant women were $86.3 \mathrm{fL}$ giving $77 \%$ sensitivity with a specificity of $71 \%$.

In our study, $\mathrm{MCV} \leq 86.3 \mathrm{fL}$ were used to detect single gene deletion in Malaysian population. This finding was in agreement with previous study $[5,10]$. The range of MCV for $-\alpha^{3.7} / \alpha \alpha$ genotype was $78-89 \mathrm{fl}$ in studies by Fucharoen $\mathrm{G}$ et al. [5], Sanchaisuriya $\mathrm{K}$ et al. [8], and Sirichotiyakul S et al. [9].

Meanwhile MCV for two of our patients identified as two gene deletion (--SEA/aa genotype) was $68 \mathrm{fl}$ and $74 \mathrm{fl}(\mathrm{MCV} \leq 80)$ respectively. They have lower value, a similar finding as previously reported in studies with $\alpha^{0}$-thalassaemia $[11,12]$.

It is important to screen for $\alpha$-thalassaemia in women with child bearing age as the disease is prevalent in Malaysia and may cause some social economic burden to the country. Fetus may be at risk to develop deletional $\mathrm{Hb}$ Barts hydrops foetalis syndrome or deletional $\mathrm{HbH}$ disease. Hydrops fetalis has been reported in Chinese-Malaysian with $0.3 / 1000$ births [13]. The projected number of pregnancies at risk and contribute for deletional $\mathrm{Hb}$ Barts hydrops foetalis syndrome and deletional $\mathrm{HbH}$ disease each year in Malays was 30 and 120 [13]. In view of its high probability, it is important for us to identify them early and the best times to catch them are doing their antenatal check-up.

During pregnancy, the reference interval of MCV for $\alpha$-thalassaemia in this present study was higher than reference interval used in normal adult $(80 \mathrm{fl})$ and this could be due to the differences in folate and vitamin $B_{12}$ status. MCV is also a poor marker of iron deficiency in pregnancy because of the physiological increased in MCV during gestation counterbalances the microcytosis of iron deficiency [14]. Generally individuals with MCV $<80 \mathrm{fL}$ or $\mathrm{MCH}<27 \mathrm{pg}$, were investigated for an underlying thalassaemia by doing hemoglobin, HPLC or electrophoresis.

In addition serum ferritin should be ordered concurrently particularly in pregnant women, although in our study, serum ferritin was not performed due to budget limitation.

A modified one-tube OF test was used as a screening method in this study to identify individuals who may be a carrier of $\alpha$-thalassaemia. This method has been proven to be useful in the prevention and control program for thalassaemia in Thailand $[5,8,15]$. But in this present study, we found $O F$ test were indiscriminative for $\alpha$-thalassaemia carrier especially $\alpha^{+}$-thalassaemia. A total of $10 \alpha^{+}$-thalassaemia carrier was negative for OF test. This study also showed that there was no significance difference in $\mathrm{OF}$ test between $\boldsymbol{\alpha}$-thalassaemia and non$a$-thalassaemia in pregnant women. Thus, we conclude that it is not a useful screening test during pregnancy.

There are several methods to confirm $\alpha$-thalassaemia carrier including dot-blot analysis, reverse dot-blot analysis, amplification refractory mutation system (ARMS), restriction enzyme (RE) digestion, denaturing gradient gel and so on. In this study, we have performed multiplex GAP PCR to detect two common deletional types of 
Citation: Hassan R, Fathma Abdullah NA, Bahar R, Ghazali S, Abdul Ghaffar NA (2013) The Value of Red Blood Cells (Rbc) Indices and Osmotic Fragility Test as Screening Tests in Malay Pregnant Women with Alpha Thalassaemia. Clinics Mother Child Health 11: 154. doi: 10.4172/20907214.1000154

Page 4 of 4

$\alpha$-thalassaemia genotypes: $\alpha^{0}$-thalassemia gene deletion $\left(^{--S E A}\right.$ and $\left.{ }^{- \text {THAI }}\right)$ and $\alpha+$-thalassaemia gene deletion ( $-\alpha^{3.7}$ deletion and $-\alpha^{4.2}$ deletion).

$-\alpha^{3.7}$-globin gene was the most common cause of $\alpha$-thalassaemia [16] and most dominant in African, Mediterranean and Asian population [2,17]. This study was performed in Kelantan, a state in Malaysia which comprised $80 \%$ of the population are Malays. Single gene deletion was found to be more prevalent with $8.1 \%$ of the patients confirmed as heterozygous $-\alpha^{3.7} / \alpha \alpha$ genotype.

The South-East Asian deletion (-SEA) is the most common $a^{\circ}$ thalassaemia variant in South-East Asian population [18]. However $\alpha^{0}$ thalassaemia with the --SEA deletion was detected in only $1.1 \%(2 / 184)$ of the Malay pregnant women studied. This finding may suggest that there is a risk having Hb Bart's hydrops fetalis baby among Malay and subsequent hematological screening and molecular analysis for a-thalassaemia should be perform in their spouses.

In conclusion, we still recommended using $\mathrm{MCV}$ and $\mathrm{MCH}$ as a screening parameters for $\alpha$-thalassaemia in pregnant women. However the cut-off value for MCV and $\mathrm{MCH}$ should be less than $86.3 \mathrm{fl}$ and 27.4pg respectively. This should be follow by screening for a-thalassaemia in spouse for further genetic counselling. In our hand, OF test has failed to predict the carrier status in pregnant women.

\section{Acknowledgement}

The authors would like to acknowledge the Universiti Sains Malaysia (USM) Research University Grant

(No. 1001/PPSP/812003) for their financial support.

\section{References}

1. Wee YC, Tan KL, Chow TW, Yap SF, Tan JA (2005) Heterogeneity in alphathalassemia interactions in Malays, Chinese and Indians in Malaysia. J Obstet Gynaecol Res 31: 540-546.

2. Guvenc B, Yildiz SM, Tekinturhan F, Dincer S, Akyuzluer I, et al. (2010) Molecular Characterization of $\alpha$-Thalassemia in Adana, Turkey: A Single Center Study. Acta Haematol 123: 197-200.

3. Weatherall DJ, Clegg JB (2001) The Thalassemia Syndromes, London, Blackwell, 2001.

4. Weatherall DJ, Clegg JB (2001) Inherited haemoglobin disorder: an increasing global health problem. Bull World Health Organ 79: 704-712.

5. Fucharoen G, Sanchaisuriya K, Sae-ung N, Dangwibul S, Fucharoen S (2004)
A simplified screening strategy for thalassaemia and haemoglobin $E$ in rural communities in south-east Asia. Bull World Health Organ 82: 364-372.

6. Tayapiwatana C, Kuntaruk S, Tatu T, Chiampanichayakul S, Munkongdee T, et al. (2009) Simple method for screening of a-thalassaemia 1 carriers. Int J Hematol 89: 559-567.

7. Lau YL, Chan LC, Chan YY, Ha SY, Yeung CY, et al. (1997) Prevalence and genotypes of alpha- and beta- thalassemia carriers in Hong Kong --implications for population screening. N Engl J Med 336: 1298-1301.

8. Sanchaisuriya K, Fucharoen S, Fucharoen G, Ratanasiri T, Sanchaisuriya P et al. (2005) A reliable screening protocol for thalassemia and hemoglobinopathies in pregnancy: an alternative approach to electronic blood cell counting. Am J Clin Pathol 123: 113-118.

9. Sirichotiyakul S, Wanapirak C, Srisupundit K, Luewan S, Tongsong T (2009) A comparison of the accuracy of the corpuscular fragility and mean corpuscular volume tests for the alpha-thalassemia 1 and beta-thalassemia traits. Int J Gynaecol Obstet 107: 26-29

10. Bowden DK, Hill AV, Higgs DR, Oppenheimer SJ, Weatherall DJ, et al. (1987) Different hematologic phenotypes are associated with the leftward $\left(-\alpha^{4.2}\right)$ and rightward $\left(-\alpha^{3.7}\right) \alpha+-$ thalassemia deletion. J Clin Invest 79: 39-43.

11. Ma ES, Chan AY, Ha SY, Lau YL, Chan L. C (2001) Thalassemia screening based on red cell indices in the Chinese. Haematologica 86: 1310-1311.

12. Savongsi O, Fuchareon S, Fuchareon G, Sanchaisuriya K, Sae-ung N (2008) Thalassemia and hemoglobinopathies in pregnant Lao women: carrier screening, prevalence and molecular basis, Ann Hematol 87: 647-654.

13. Aliza MY, Nor Asiah M, Manaf AA, Chin YM, Normi M, et al. (2012) Prevalence and Disease Burden of Common Alpha Thalassemia Deletions in Malaysian Blood Donors: A multi ethnic population. IJSRP 2: 1-5.

14. Milman N, Byg KE, Agger AO (2000) Hemoglobin and erythrocyte indices during normal pregnancy and postpartum in 206 women with and without iron supplementation. Acta Obstet Gynecol Scand 79: 89-98.

15. Tongpraset F, Sirichotiyakul S, Piyamongkol W, Tongsong T (2010) Sensitivity and Specificity of simple erythrocyte osmotic fragility test for screening of alpha-thalassemia-1 and beta-thalassemia trait in pregnant women, Gynecol Obstet Invest 69: 217-220.

16. Shaji RV, Srivastava A, Chandy M, Krishnamoorthy (2000) A single tube multiplex PCR method to detect the common a+ thalassemia alleles. Blood 95: 1879-1880.

17. Neishabury M, Abbasi-Moheb L, Poorfathollah AA, Kahrizi K, Keyhany E, et al (2001) Alpha-Thalassemia: Deletion Analysis in Iran. Arch Iran Med 4: 160-164.

18. Winichagoon P, Higgs DR, Goodbourn SE, Clegg JB, Weatherall DJ, et al (1984) The molecular basis of $\alpha$-thalassemia in Thailand. EMBO J 3: 1813-1818. 